\title{
Biology of Juvenile Ozernovskaya Sockeye Salmon Oncorhynchus nerka (the Ozernaya River, Basin of the Kurilskoe Lake) during Downstream Migration and Early Marine Period of Life
}

\author{
Maksim Koval $^{1}$, Sergey Gorin ${ }^{2}$, Alexander Vasilenko ${ }^{3}$, Vladimir Dubynin ${ }^{1}$ and Anton Klimov ${ }^{1}$ \\ ${ }^{1}$ Kamchatka Research Institute of Fisheries and Oceanography (KamchatNIRO), \\ 18 Naberedznaya Str. Petropavlovsk-Kamchatsky, 683000, Russia \\ ${ }^{2}$ Russian Federal Research Institute of Fisheries and Oceanography (VNIRO), \\ 17 Verkhnyaya Krasnoselskaya, Moscow, 107140, Russia \\ ${ }^{3}$ Lomonosov Moscow State University (MSU), 1 Leninskiye Gory, Moscow, 119991, Russia
}

Keywords: Pacific salmon, critical period of life, abundance, mortality, estuary, coastal waters, forecast, Ozernaya River

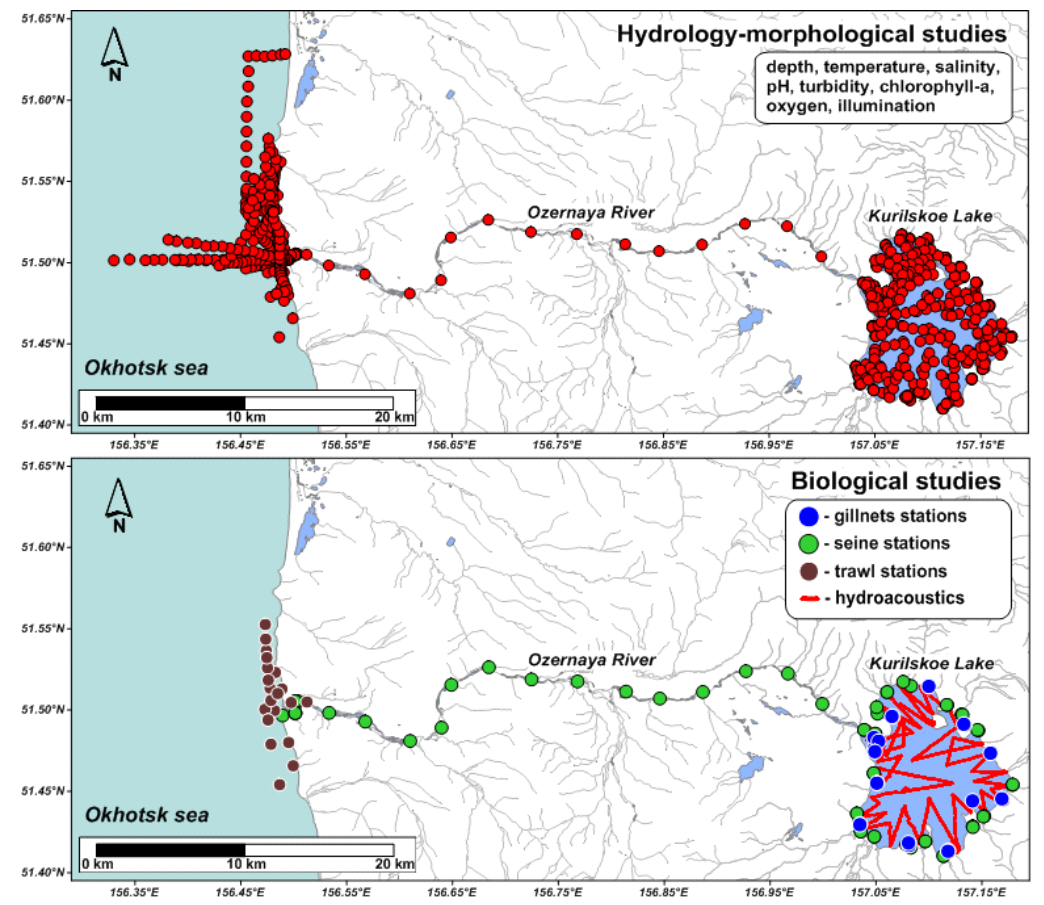

Fig. 1. Kurilskoe Lake and Ozernaya River with scheme of hydrology-morphological and biological stations conducted June-August 2017.

Ozernovskaya sockeye salmon is the largest and the most studied population of Asian sockeye salmon, spawning in the basin of Ozernaya River and Kurilskoe Lake (South Kamchatka) ${ }^{1}$. In the 1930s, results of studying this population were generalized for the first time (Krokhin and Krogius 1937), and since 1940, monitoring research has been provided (Anon 2010; Koval et al. 2014). During this period the biology of Ozernovskaya sockeye salmon in the course of spawning, juvenile foraging in the Kurilskoe Lake (before migration into the Ozernaya River), the marine period of life, and spawning migration has been determined (Bugaev 1995, 2011; Bugaev et al. 2009). Yet,

\footnotetext{
${ }^{1}$ The basin and estuary area of the Ozernaya River are located outside south and south-west of the Kamchatka Peninsula. The river outflows from Kurilskoe Lake and inflows to the Okhotsk Sea (see Fig. 1). The length of the Kurilskoe Lake is $\sim 12.4 \mathrm{~km}$, its width is $\sim 10.6 \mathrm{~km}$, its area is $\sim 76 \mathrm{~km}^{2}$, its volume is $\sim 14.2 \mathrm{~km}^{3}$, its height of the surface above sea level is $\sim 81 \mathrm{~m}$. The lake has a deep hollow $(\sim 300 \mathrm{~m}$ ), located between several active volcanoes. The length of the Ozernaya River is $\sim 45 \mathrm{~km}$, its vertical drop from the head to the mouth is $\sim 80 \mathrm{~m}$; the channel of the river is weakly branched, with a stepped bed in the up reach and with numerous rapids in the low reach. The average annual water discharge (13 km upstream from the river mouth) is $48.9 \mathrm{~m}^{3} / \mathrm{s}$ (1976-2003). At the mouth of the Ozernaya River is located at Ozernovsky Village - the main center of the sockeye salmon fishery in the Russian Far East.
} 
until recently the biology during juvenile downstream migration and early marine period has been poorly understood, although it is known that for some Pacific salmon species (i.e., pink and chum salmon) migrations and period in estuaries and nearshore are the most critical periods of life, forming generation abundance (Karpenko 1998; Levings 2016). A high mortality of juvenile salmon during these periods of their life history makes it difficult to forecast adult returns, which are necessary for efficient stock management and sustainable fishing (Shevlyakov and Koval 2012).

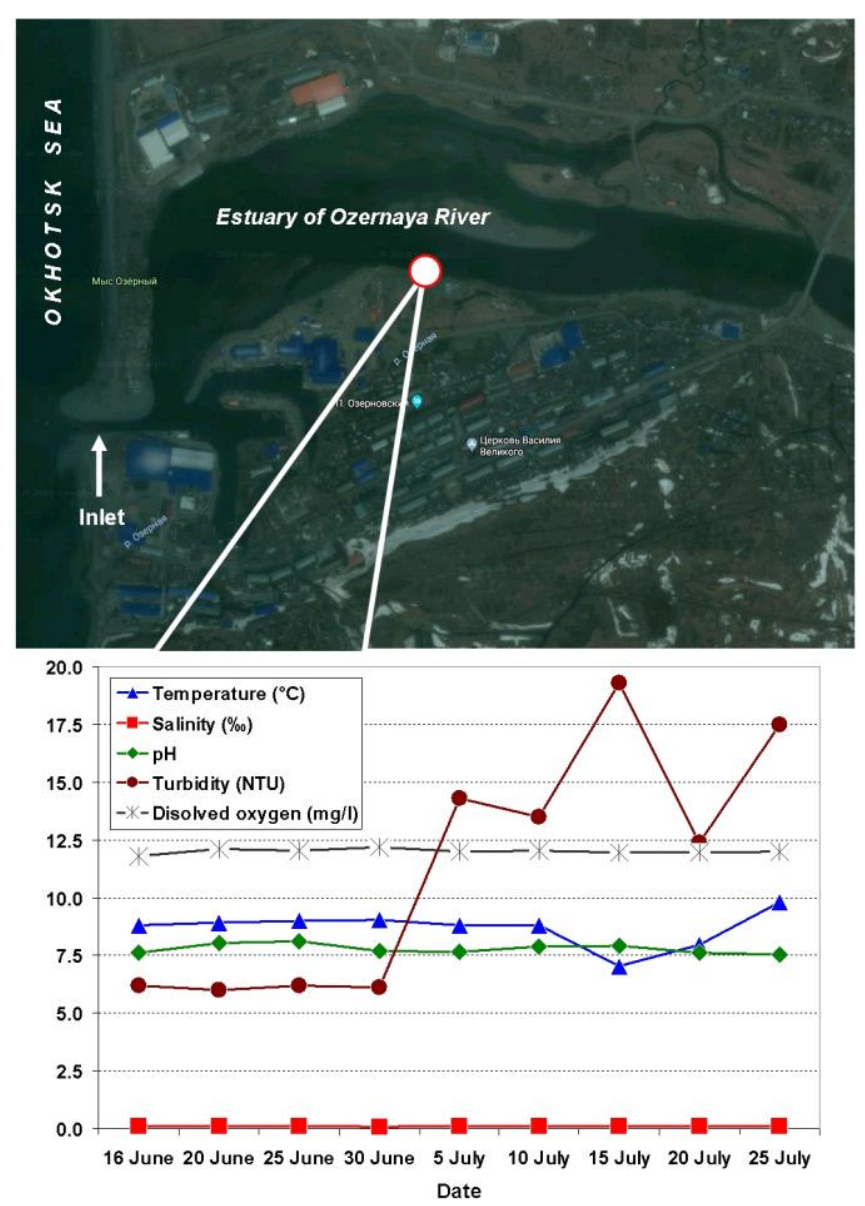

Fig. 2. Estuary of the Ozernaya River and dynamics of some hydrological characteristics ( $1 \mathrm{~km}$ from river mouth) from 16 June to 25 July 2017.

An integrated field study of juvenile ozernovskaya sockeye salmon in the basin of Kurilskoe Lake, the Ozernaya River and adjacent waters of the Okhotsk Sea was carried out from June-August 2017 (Fig. 1). The field hydrological and morphological studies were completed using standard methods (Anon 1993; Federal Scientific Research Institute of Fisheries and Oceanography 2011). This included measuring water depth (Kurilskoe Lake, Ozernaya River estuary and coastal waters of the Okhotsk Sea), monitoring the water level, temperature, and salinity at seven stationary hydrological stations (lower reach and estuary of the Ozernaya River, coastal waters of the Okhotsk Sea), measuring speed and direction of the current, and water discharge (Ozernaya River), and hydrological surveys, which measured temperature, salinity, PH, turbidity, chlorophyll-a, dissolved oxygen, and illumination (Kurilskoe Lake, Ozernaya River, coastal waters of the Okhotsk Sea). Measuring the hydrological characteristics of the environment was completed using the autonomous devices GMU-2 and STD (CDB GMP, Obninsk), DST centiTD, DST tilt, DST CT (Star-Oddi Ltd.) and multiparameter probe AAQ-RINKO Profiler (JFE Advantech Ltd.). The distribution of the juvenile fish in the waters of Kurilskoe Lake was studied and biological data was obtained with the use of the BioSonics DT-X scientific echosounder, gillnets (with mesh size $18 \mathrm{~mm}$ ) and 3/8 m fingerling seine, in the basin of the Ozernaya River;fingerling seine (river and estuary) and beam-trawl 2.6/8.2 m (estuary), in the coastal waters of the Okhotsk Sea;beam-trawl (the mesh size in the cod-end of the seine and trawl was $4 \mathrm{~mm}$ ). 
The methods of the hydroacoustics observations and of the control catches was described in detail earlier (Koval et al. 2012; 2013). The seine survey from the head to the mouth of the Ozernaya River was carried out during the day on 16 June 2017 (the distance between the stations of seining was $3 \mathrm{~km}$ ). During the survey, the fish were caught in different river biotopes (middle pelagic zone, littoral zone, pelagic zone of river creeks and channels). After that the survey, the control seining was carried out during the day in the littoral zone of the Ozernaya River estuary at the same station that was placed in the river $\sim 1 \mathrm{~km}$ upstream from the river mouth, once per five days from 20 June to 25 July 2017 (Fig. 2). The trawl fishing in the Ozernaya River estuary and coastal waters of the Okhotsk Sea was carried out on 1, 6, 17, 18, and 23 July 2017. All control fishing operations were carried out with simultaneous measuring of main environmental abiotic parameters with the AAQ-RINKO Profiler probe. More than 1,000 hydrological, 23 gillnet, 60 seine, and 20 trawl stations were conducted during the period of our field research. The distance of the hydroacoustics tracks in the Kurilskoe Lake was $262 \mathrm{~km}$.

The main goal we had set in the framework of this study was to estimate the role of the downstream migration and early marine period of life in the formation of the stock abundance of Ozernovskaya sockeye salmon. For this goal, in addition to the results of our field study in 2017, we also used: 1) data on the abundance and biological characteristics of juvenile Ozernovskaya sockeye salmon, migrated from Kurilskoe Lake (obtained by workers of KamchatNIRO at the Ozernovsky Biological Station placed at the head of the Ozernaya River); 2) results of trawl surveys by KamchatNIRO in coastal waters of the West Kamchatka (conducted since 2004) (Koval et al. 2011); 3) data of forecasts of adult sockeye salmon returns into the Ozernaya River basin for last 10 years.

It is now known that in the first year of life, after leaving the redds, juvenile Ozernovskaya sockeye salmon emigrate from the lake spawning grounds (and from the lake tributaries) for pelagic foraging in Kurilskoe Lake (Bugaev et al. 2009; Kirillova et al. 2015). The most abundant underyearling sockeye salmon are from river spawning grounds (placed in the up reach of the Ozernaya River), they also migrate into the lake for foraging, while a minor part migrate downstream to the river mouth (where they create aggregations normally in July) (Kirillova et al. 2014; 2017; Pavlov et al. 2015). In the Kurilskoe Lake, juvenile sockeye salmon can stay for foraging from one to three years (very rarely-four) before leaving for the sea. The dominance among the smolts (70-90\%) is the group age of 2+. The downstream migration of sockeye salmon smolts down the Ozernaya River starts in late May or early June and stops in the last half of July or early August. The fish usually migrate at night, and the migration mainly stops at dawn (Bugaev et al. 2009). Juvenile sockeye salmon of different ages occupy different biotopes in the Ozernaya River: underyearlings inhabit in the littoral zone near the shores with weak currents, and smolts occur in the midstream of the water flows (Kirillova et al. 2014). A small abundance of underyearling sockeye salmon can leave the river for the sea (Pavlov et al. 2015), but these fish have been never been recorded in adult returns into the basin of the Ozernaya River.

The results of our field study from June-August 2017 indicated, that for the research period the Ozernaya River passed the period of high flows (in the inlet a water discharge was $>60 \mathrm{~m}^{3} / \mathrm{sec}$ ). A flood during high water period began in mid-May and reached its peak on 20 June. During flood recession (in July) there were several weak and one strong (25-27 July) rain floods. As a result, in August, the water discharge of the river decreased. The speed of the current on the river mainstream was more than $1.0-1.5 \mathrm{~m} / \mathrm{sec}$.

The Ozernaya River estuary is a small and shallow-water object (length $\sim 1.6 \mathrm{~km}$; width up to 200-300 m; depth <1.0-1.5 m; see Fig. 2). It is connected with the sea through a narrow (<30 m) and short (150 m) channel (hereinafter «inlet»). Marine tides near the Ozernaya River mouth are irregular, once half a day, from $1 \mathrm{~m}$ in the neap tide and up to $2.2 \mathrm{~m}$ in spring tide. On entering the estuary, the tides quickly vanish: never more than $40 \%$ from initial value; just $0.8 \mathrm{~km}$ inland from the sea. The tides never reached $6 \mathrm{~km}$ inland from the sea, where the first river rapids are. The water current in the inlet in summer was directed toward the sea no matter the tidal phase, and the maximal speed of the flow at low tide was 1.9-2.5 m/sec. At high tide the speed decreased but was anyway high $(1.1-1.7 \mathrm{~m} / \mathrm{sec})$. In summer 2017 , the water in the estuary was permanently fresh. Slight occurrence of salty waters in the inlet began in the last days of August when the river flow was reduced to $45 \mathrm{~m}^{3} / \mathrm{sec}$. With this connection and considering the long-term characteristics of the Ozernaya River flow, the salinization of the estuary in the summer period is a very rare and short phenomenon. It cannot occur every year and only on days of very poor water discharges. In most cases the saline waters enter the estuary for several hours, and the square of salinization covers just few hundred meters from the sea. 


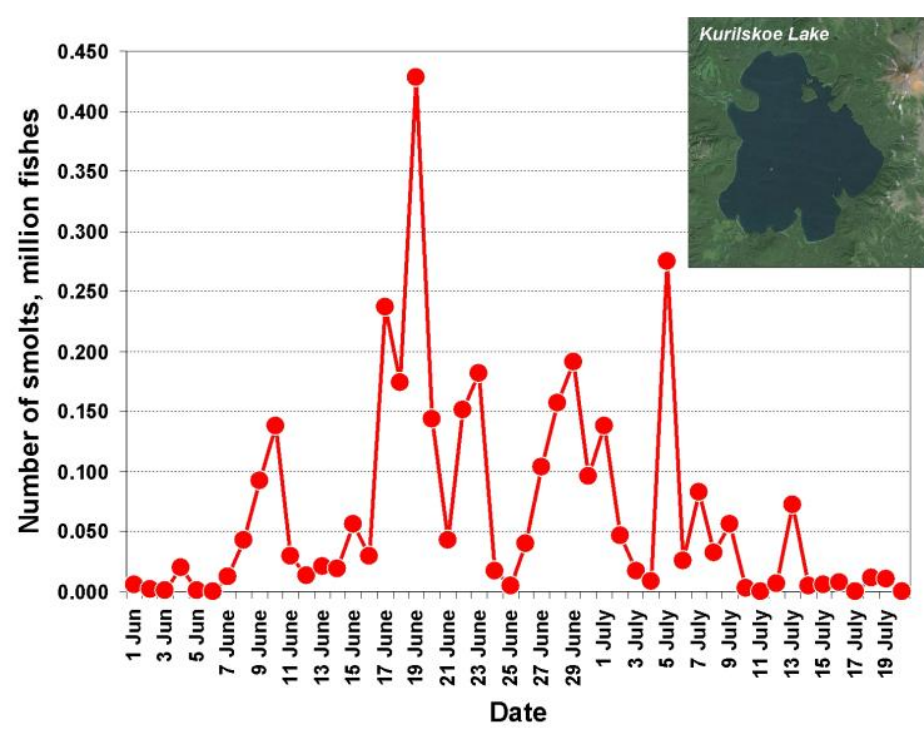

Fig. 3. Dynamics of downstream migration of sockeye salmon smolts from Kurilskoe Lake, June-July 2017 (according to control catches in head of the Ozernaya River).

On the catch data of the control trap in the head of the Ozernaya River, the downstream migration of juvenile sockeye salmon from Kurilskoe Lake in 2017 began on 1 June and was over on 19 July (Fig. 3). From the results of calculations (provided on the base of control trap catches) it was found that $3.255^{2}$ million sockeye salmon smolts migrated to the lake for this period. The maximal number of migrants was observed on 19 June (0.428 million fishes) and on 5 July ( 0.275 million fishes). The migrants abundance on the other days usually did not exceed 0.100-0.200 million fishes. The portion of fish of age group 2+ was $94.0 \%$ in the total number of the smolts, and the portions of $1+$ and $3+$ fishes were $1.8 \%$ and $4.2 \%$ respectively. The maximal length (AC) and weight of smolts in the control trap catches from 10 June to 10 July varied from 7.0 to $10.4 \mathrm{~cm}$, and from 2.39 to $9.53 \mathrm{~g}$ (averaged 8.3 $\mathrm{cm}$ and $5.41 \mathrm{~g})(n=400)$. The average body length and weight of the smolts $1+$ was $7.9 \mathrm{~cm}$ and $4.92 \mathrm{~g}(n=7) ; 2+-$ $8.3 \mathrm{~cm}$ and $5.34 \mathrm{~g}(n=376) ; 3+-9.1 \mathrm{~cm}$ and $7.22 \mathrm{~g}(n=17)$.

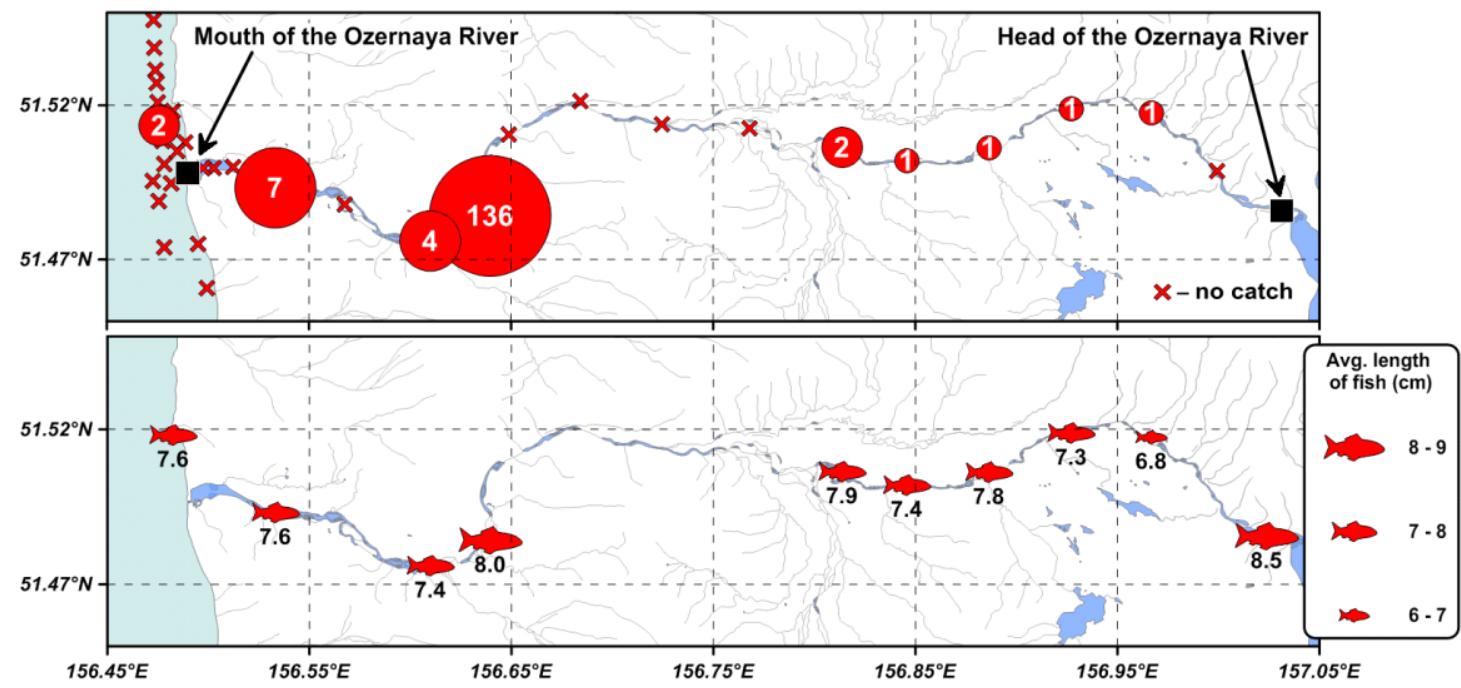

Fig. 4. Distribution of abundance (ind.) and average length $(\mathrm{cm})$ of sockeye salmon smolts in seine catches in the Ozernaya River (16 June 2017) and in trawl catches (6 July 2017) in coastal waters of the Okhotsk Sea.

\footnotetext{
${ }^{2}$ It should be understood, that this estimate is relative, not absolute (the same applies for estimates of fish abundance by data of trawl surveys, see below). Such indicators can be used to characterize abundance for different generations only in a comparative aspect-based on long-term series data.
} 
At all 15-ht stations, used during the seine survey in the Ozernaya River 16 June 2017 (during the mass migration of juvenile sockeye salmon from Kurilskoe Lake), 4449 juveniles of chum salmon (94.0\%), 153 sockeye salmon smolts (3.2\%) (Fig. 4), 59 juveniles of Dolly Varden (1.3\%), $42(0.9 \%)$ juveniles of coho and $4(<0.1 \%)$ of pink salmon were caught. At the station №15, placed in Ozernaya River estuary ( 1 km from the inlet, see Fig. 2), there were diadromous starry flounder (20 individuals) and threespine stickleback (4 individuals) found in the catches. Sockeye salmon smolts in the Ozernaya River were observed mostly in the mainstream (where the average speed of water current was $\sim 1 \mathrm{~m} / \mathrm{sec}$ or greater), and in the pelagic zones of river backwaters and channels (where the water current is slow). In such areas of the river, the total portion of smolts was $13.0 \%$ of the total number of catches. At the same time, juvenile individuals of other salmon species were observed everywhere in the littoral zone (where speed of the current was not $>0.3 \mathrm{~m} / \mathrm{sec}$ ). Sockeye salmon smolts were sporadic at such areas $(0.3 \%)$. The body length and weight of sockeye salmon smolts in the seine catches was $6.8-10.1 \mathrm{~cm}(8.0 \mathrm{~cm})$ and $2.23-9.16$ $\mathrm{g}(4.17 \mathrm{~g})$ respectively.

In littoral zone of the Ozernaya River estuary (at base station $\sim 1 \mathrm{~km}$ inland from the inlet, see Fig. 2) at 8-ht seine fishing operations (carried out from 20 June to $25 \mathrm{July}, 2017) 3710$ juveniles of chum salmon (96.6\%), 58 underyearling sockeye salmon $(1.5 \%), 45$ coho salmon $(1.2 \%), 12$ Dolly Varden $(0.3 \%), 7$ three spine stickleback $(0.2 \%)$, and 1 starry flounder $(<0.1 \%)$ were caught. There were no sockeye salmon smolts in the catches. Underyearling sockeye were sporadic in the estuary after 5 July, and their number in the catches increased (the maximal number-31 individuals were caught on 15 July). The body length of under-yearlings ranged from $2.8-4.2 \mathrm{~cm}$ (averaging $3.4 \mathrm{~cm}$ ), and the weight of under-yearlings ranged from $0.13-0.60 \mathrm{~g}$ (averaging $0.30 \mathrm{~g}$ ). As indicated by the data, juvenile chum salmon predominated in the catches in the littoral zone of mainstream and estuary of the Ozernaya River during observation period, which corresponds with the data of previous studies (Kirillova et al. 2014; 2017; Pavlov et al. 2015).

At 2-ht trawl stations, conducted in the pelagic zone of the Ozernaya River estuary during the day on 1 and 17 July 2017, nine chum salmon juveniles were caught. In the coastal waters of the Okhotsk Sea, adjacent to the Ozernaya River mouth, the invertebrates (jellyfish and mysids) were the dominant species caught in the trawls, while juvenile fish were sporadic (indicating that the fish could escape the trawl). The total catch at 18-ht trawl stations, conducted from marine side adjacent to the Ozernaya River mouth, included 2 smolts of sockeye salmon (caught on 6 July 2017) and two smolts of chum salmon (caught on 17 and 18 July 2018). These fish were caught at the stations placed $\sim 2.5-3.0 \mathrm{~km}$ northward from the river mouth (Fig. 4). The body length and weight of the sockeye salmon smolts caught in the trawls was 7.4-7.8 cm (averaging $7.6 \mathrm{~cm}$ ) and 3.40-4.12 g (averaging $3.76 \mathrm{~g}$ ).

It was previously thought, that sockeye salmon smolts migrated from the head to mouth of the Ozernaya River over a period of 5-10 days (Bugaev et al. 2009). Our results indicate that the period of their migration can be much shorter. Considering the distance from the head to mouth of the Ozernaya River $(\sim 45 \mathrm{~km})$, the average speed of water current in the mainstream $(>1 \mathrm{~m} / \mathrm{sec}$ ) and the stable speed of swimming fish (approximately $0.5 \mathrm{~m} / \mathrm{s}$ for juvenile sockeye salmon; Bell, 1986), the period to emigrate from the river head to mouth is about 7 hours. The dark time on the latitude of the Ozernaya River during the sockeye salmon migration is $7.5-8$ hours. In this way the majority of sockeye salmon smolts emigrating from Kurilskoe Lake over 24 hours, can reach the coastal waters of the Okhotsk Sea during the night ${ }^{3}$. Only those migrants which failed to reach the sea in one night can be seen in the river during the day time. That could be because juvenile sockeye salmon, migrated from Kurilskoe Lake passed smoltification and havealready adapted to pelagic way of life. The fish are poorly adapted to stay in the hydrological conditions of the Ozernaya River, and therefore quickly leave the river for pelagic foraging in coastal waters of the Okhotsk Sea. Moreover, the fish, which a stay in the low reach of the river in day time, strive for the lake-type biotopes (i.e., the pelagic zone of the river backwaters, inlets and channels with a weak stream). It should be noted that similar features in the biology of sockeye salmon smolts during downstream migration from lakes in other areas of reproduction have also been observed (Hartman et al. 1967).

\footnotetext{
${ }^{3}$ Such conclusion can be confirmed by results of study on the speed of the migration of sockeye salmon smolts in the basin of the Fraser River (British Columbia), which can reach from $\sim 50$ to $220 \mathrm{~km}$ per day (Clark et al. 2016).
} 


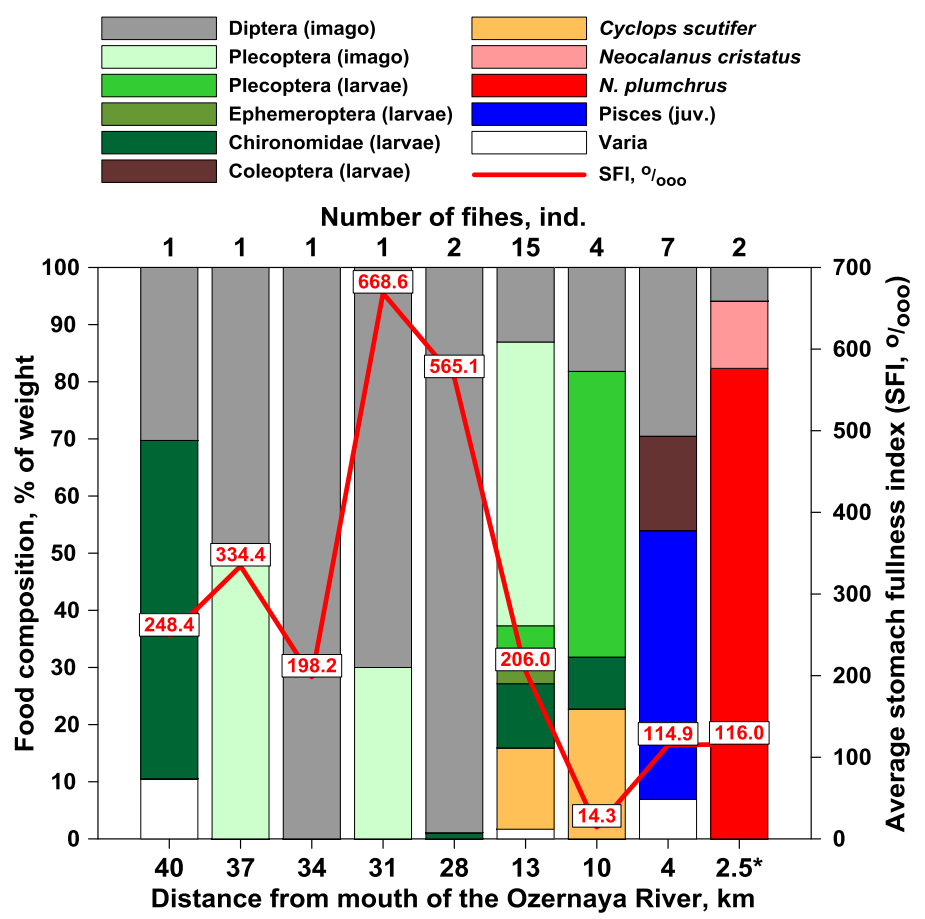

Fig. 5. Food composition (\% of weight) and average stomach fullness index (SFI, \%oo) of sockeye salmon smolts in the Ozernaya River, 16 June 2017 (*-coastal water of the Okhotsk sea, 6 July 2017).

The following is from analysis of stomach contents of sockeye salmon smolts $(n=34)$ during their migration in the Ozernaya River, where the fish are feeding intensely (Fig. 5). During the seine survey on 16 June 2017, the stomach fullness indexes (SFI) of some smolts in the river were 500-700\% no smolts with empty stomachs in the samples. The main prey item in pelagic zone of the Kurilskoe Lake for juvenile sockeye salmon was planktonic Cyclops scutifer (less often-Daphnia longiremis) (Bugaev et al. 2009), during the migration the fish were feeding on the larval and imago amphibian insects (Ephemeroptera, Plecoptera, Chironomidae, etc.). Imago, larvae and pupas of various terrestrial insects and C. scutifer, washed out of Kurilskoe Lake into the Ozernaya River (especially during the floods) can make up a huge part of the smolts' diet (Kirillova et al. 2015). Most likely, C. scutifer become concentrated in the biotopes which have a weak current, and are preferred by sockeye salmon smolts which failed to emigrate quick. Residuals of juvenile fish were found in stomachs of sockeye salmon smolts in the lower reaches of the river. On entering the sea, juvenile sockeye salmon immediately changed their diet, and started to consume marine zooplankton - regular food during their sea life (Karpenko et al. 2013), although some residuals of river food can still be found in their stomachs (like imago of Diptera) (Fig. 2).

After downstream migration in the river, sockeye salmon smolts enter the Ozernaya River estuary. As it was mentioned above, in summer 2017 the hydrological conditions there were quite stable ${ }^{4}$ and very similar to conditions in the river. This is why in the summer season the Ozernaya River estuary is the area inhabited by juvenile fish of various salmonid species, some of these species use it as their feeding and nursery grounds before leaving for the sea (chum and coho salmon, Dolly Varden) and the other species use it as a transit zone before their up-stream migration in the river (coho salmon and Dolly Varden) (Pavlov et al. 2015; our data). At the same time, according to our data, the estuary is a transit area for the sockeye salmon smolts. The smolts don't stay there, instead they leave for the sea immediately. Juvenile salmonids from the Ozernaya River can leave for the sea irrespective of ebb tide phase, and the fish which entered the coastal waters never come back into the river (Pavlov et al. 2015). The other fish species are quite abundant in estuaries of the West Kamchatka in summer season (threespine stickleback and starry flounder), and from time to time can enter the site from the Okhotsk Sea with the tides due to the hydrological specifics of the Ozernaya River estuary.

\footnotetext{
${ }^{4}$ For the period of our observations (from 5 July to 25 July 2017), in the Ozernaya River estuary there was only a slight increase in the water turbidity which was correlated with the rainfalls floods during the period this occurred (see Fig. 2).
} 

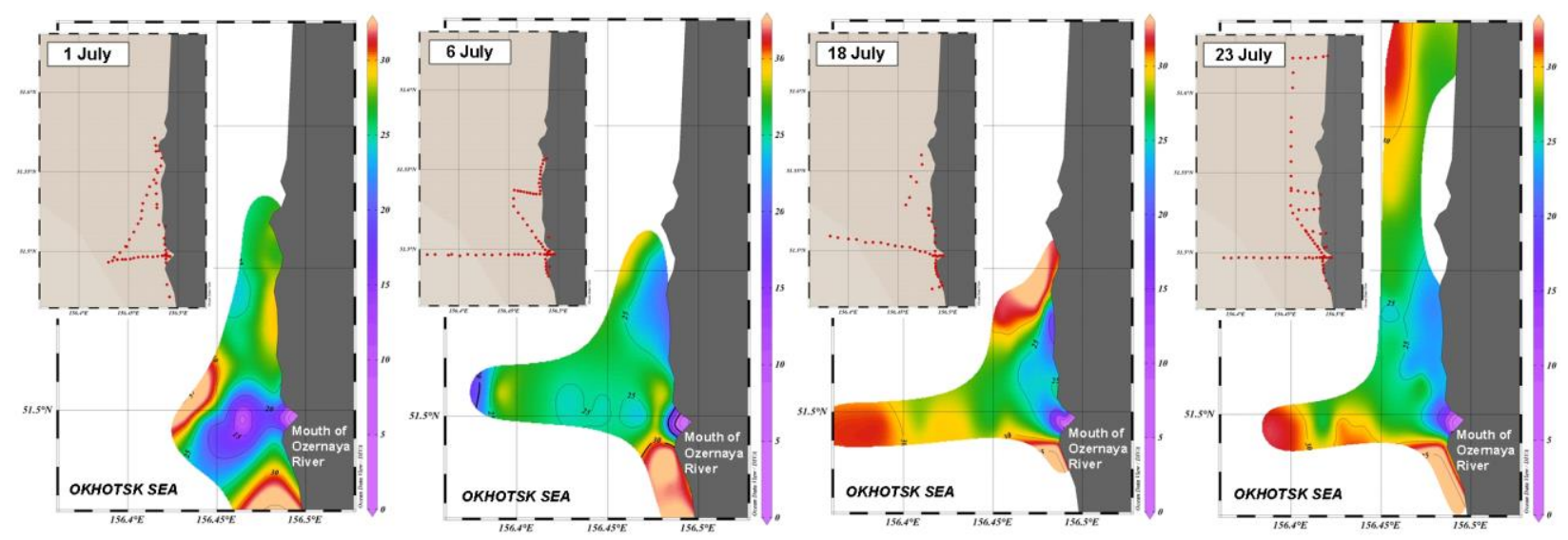

Fig. 6. Distribution of surface layer salinity (\%o) in coastal waters of the Okhotsk sea adjacent to mouth of the Ozernaya River, July 2017.

The hydrological surveys, carried out in the coastal waters of the Okhotsk Sea in July 2017, have indicated that there is a formation of a huge zone of mixing the river and marine waters in summer months in the waters adjacent to the inlet of the Ozernaya River (Fig. 6). The «core» of this zone (with salinity gradient from 0 to $15-$ $20 \%$ and temperature from 6 to $8^{\circ} \mathrm{C}$ ) is placed in vicinity of the river inlet. The water there is well mixed vertically, and therefore horizontal temperature and salinity gradients dominate in this area of the seaside. Seaward from the «core» there is much longer «peripheral» part of the mixing zone with salinity gradient from $15-20 \%$ to $31-32 \%$ and the temperatures from 8 to $11^{\circ} \mathrm{C}$. A thin layer (up to $\sim 0.5 \mathrm{~m}$ ) of freshened water covers the sea water. In July 2017, due to the permanent flow of the river water the mixing zone at sea enlarged, and the outer edges moved away (Fig. 6). Enlarging the zone went in two directions: northward along the coast (for a distance up to $10-15 \mathrm{~km}$ ) and eastward from the coast (up to 5-7 km). By late July, the mixing zone from the flow of the Ozernaya River had joined with the mixing zones of other rivers, moving it north.

The data obtained confirms that in the summer season (especially in the high-water years) on the West Kamchatka a narrow (width of several kilometers), but very long (possibly up to several hundred kilometers) freshened zone can be formed, uniting inlet areas of several rivers in this region. This is due to the effect of freshening continental flow, greatly increased during spring and summer floods. The other peculiarity of this area is that in June-August the southern part of the coast of West Kamchatka is influenced by the Pacific Ocean waters, transformed and cooled in the Kuril straits. This is why the water temperature increases northward from Cape Lopatka, and the most warmed area of the West Kamchatkan shelf is between 52 and $56^{\circ} \mathrm{N}$ (the difference between the temperatures on the south and in the central part of this area can reach $2-3^{\circ} \mathrm{C}$ ) (Anon 1998).

On the long-term data of the trawl surveys by KamchatNIRO, the catches of juvenile salmon (including sockeye salmon) on the southwest coast of Kamchatka are always maximal at the surface water temperatures ranged as $10-13^{\circ} \mathrm{C}^{5}$. The major schools of the juvenile fish are usually connected to the mouths of big rivers (Ozernaya, Opala, Bolshaya, Kihchik, Pymta, Kol' et al.), from there the salmon smolts usually migrate northward. The main abundance of sockeye salmon juveniles, foraging on the West Kamchatkan shelf, is formed by Ozernovskaya sockeye salmon, as it is the most abundant population in mentioned area (Koval et al. 2011).

As shown in Fig. 7, during the trawl survey, conducted from 30 July to 11 August 2017, the water temperature in the coastal waters of the Okhotsk Sea at the same latitude as the Ozernaya River was $<10^{\circ} \mathrm{C}$. The major schools of juvenile sockeye salmon ( $97 \%$ of total sockeye abundance in trawl catches) were observed at the stations north of the river mouth, in the area where the surface temperatures were $10-13^{\circ} \mathrm{C}$. Analysis of the dynamics of body length and weight of the smolts which migrated from Kurilskoe Lake to the trawl survey in 2017 has indicated that the average daily growth of juvenile Ozernovskaya sockeye salmon at sea can be $0.14-0.15 \mathrm{~cm}(1.1-1.2 \%$ of the body

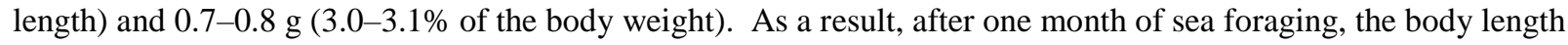
can increase $\sim 1.5$ times, and the weight $\sim 5$ times.

\footnotetext{
5 Apparently, this temperature is optimal and provides the most effective energy metabolism of the organism and the highest growth rate of Pacific salmon juveniles (Karpenko et al., 2013).
} 


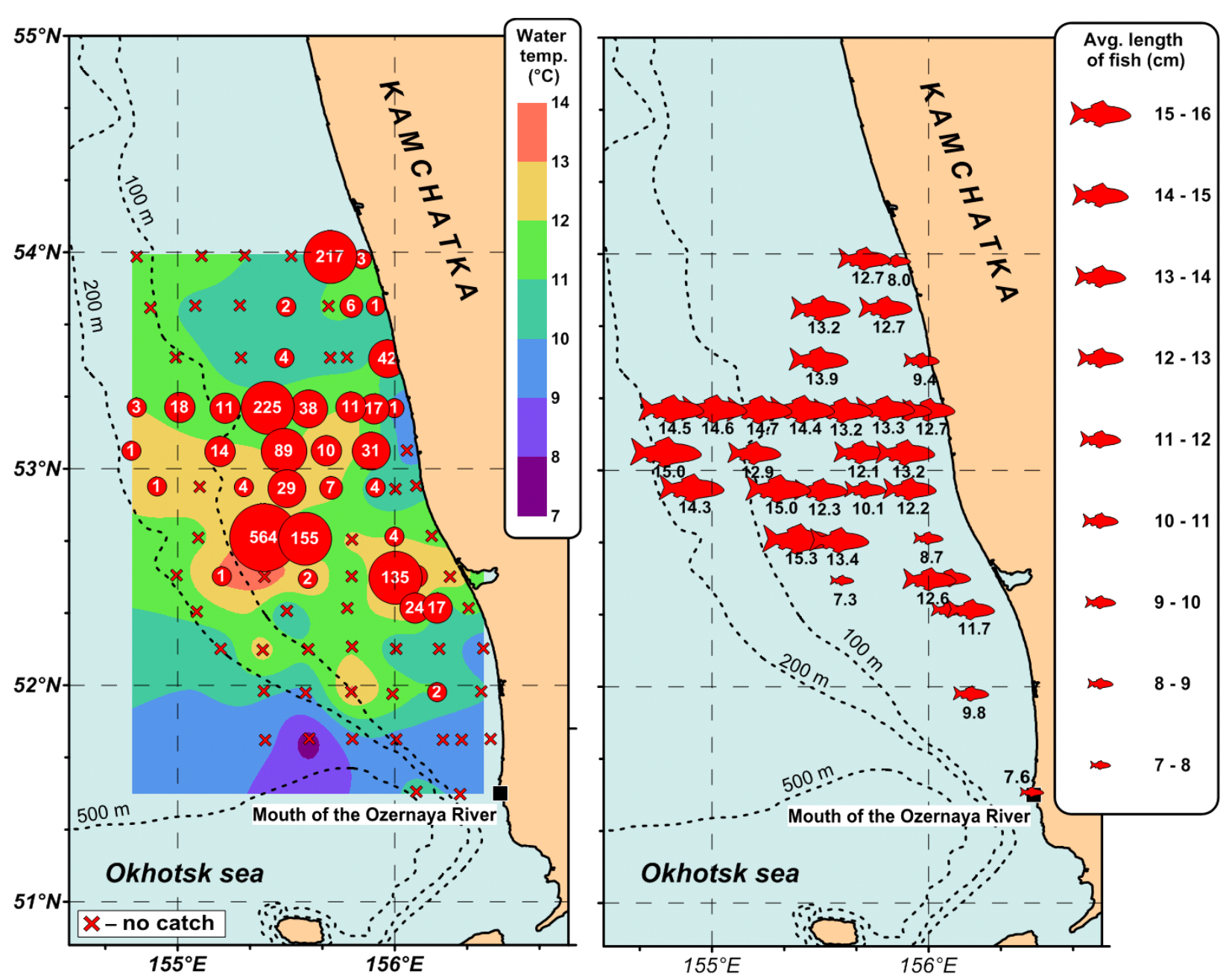

Fig. 7. Distribution of surface water temperature $\left({ }^{\circ} \mathrm{C}\right)$, abundance (ind.) and average length (cm) of juvenile sockeye salmon (by data of trawl survey conducted in coastal waters of the Okhotsk Sea, 30 July-11 August 2017).
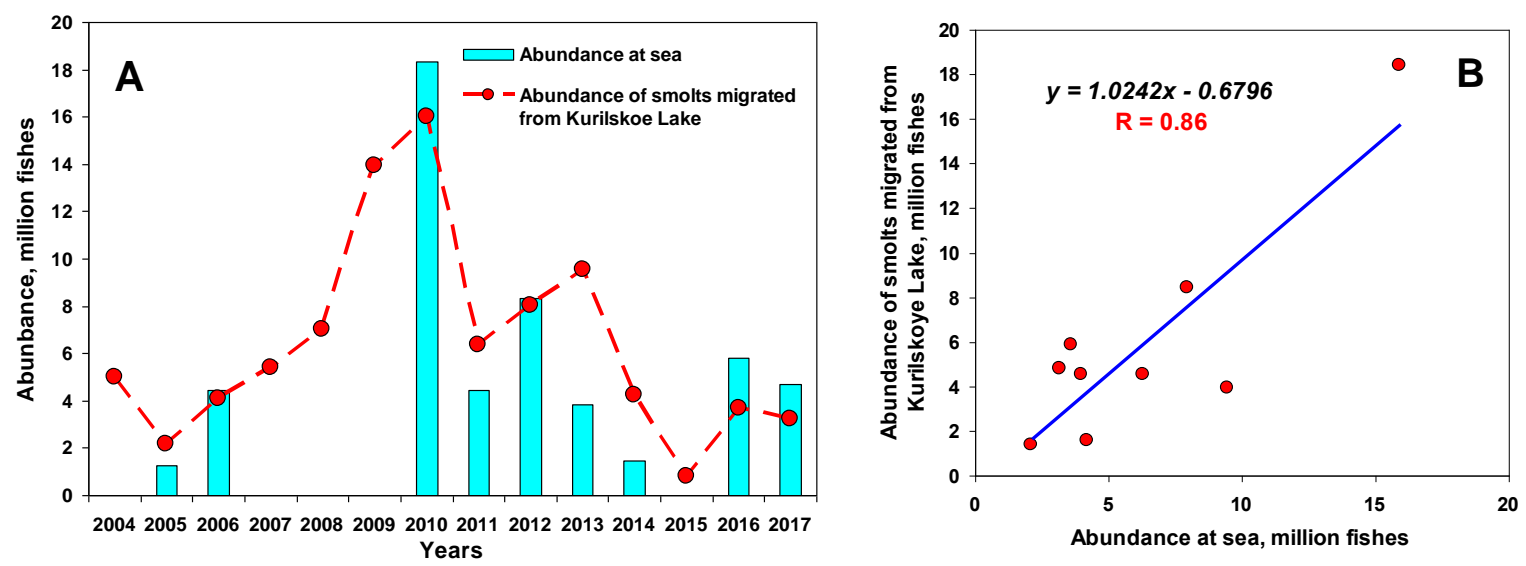

Fig. 8. Total abundance of smolts migrated from Kurilskoe Lake (June-July) and total abundance of sockeye salmon juveniles estimated on trawl surveys at coastal waters of the Okhotsk sea (July-August), 2004-2017 (Fig. 8a); Correlation between these two indicators (Fig. 8b). 
Thus, environmental conditions existing during the period of downstream migration and the early marine period of life of Ozernovskaya sockeye salmon can play a very important role in their biology. The geographical position of the Ozernaya River basin and the hydrological regime in the channel and estuary of this river can determine the speed of the migration of sockeye salmon smolts from Kurilskoe Lake to the sea. As a result, there is low mortality from riverine predators (Hartman et al. 1967; Clark et al. 2016), which are also practically absent in the basin of the Ozernaya River during the smolts migration, based on our observations. The temperature regime in the coastal waters of West Kamchatka predetermines the general direction of juvenile migration in the first months of sea life and provides conditions for a high growth rate and a quick escape from the pressure of various marine predators (it is likely that areas with the higher water temperatures are more favorable for fish to find food resources). Furthermore, the extended zone of freshening sea can promote effective restructuring of osmoregulation and adaptation of fish on the transit from freshwater to marine period of life. As Ozernovskaya sockeye salmon migrate to sea when they are quite big (the body length 7-10 cm) and ready to live in pelagic habitat (can immediately start to consume energy-valuable marine food, which also contributes into the growth rate increase), the total survival in the early marine period should be quite high.

As a result, as illustrated in Fig. 8, the total relative abundance of juvenile sockeye salmon, counted in the coastal waters near the southwest Kamchatka coast (calculated on the data by trawl surveys in 2005, 2010-2014 and 2016-2017), was very similar to the abundance of sockeye salmon smolts migrated from Kurilskoe Lake for same period (Fig. 8a). The correlation coefficients $r$ between these two indicators is 0.86 . In this case, the difference between the numbers (averaged for all years of the observations) was only 0.525 million fishes, which is within an error corridor for the total generation abundance assessment, provided by different methods (Fig. 8b).

The presented data can confirm the conclusion about the high survival of Ozernovskaya sockeye salmon (or low interannual variability of this indicator) during downstream migration and early marine foraging; one of the most critical periods in the life cycle of Pacific salmon. In our opinion, this feature of the biology of Ozernovskaya sockeye salmon supports the high accuracy of the forecasted adult fish returns in the Ozernaya River in the last decade, when one of the basic sources for this forecast has become the estimation of smolt abundance as they migrate from Kurilskoe Lake. Thus, the average accuracy of the forecast of the returns of Ozernovskaya sockeye salmon (expressed as the ratio between forecasted abundance of the returns and the in-fact returns into the Ozernaya River basin) for recent 10 years was $103.6 \%$.

The field studies were supported by the Russian Foundation for Basic Research (project nos. 17-05-01224).

\section{REFERENCES}

Anon. 1993. Hydrological observations and activities at hydrometeorological network in river estuarine areas: Methodological Recommendations. Gidrometeoizdat. Moscow. (in Russian).

Anon. 1998. Hydrometeorology and hydrochemistry of seas (Vol. IX: Okhotsk sea. Issue 1: Hydrometeorological conditions). Gidrometeoizdat. St. Petersburg. (in Russian).

Anon. 2010. Sockeye salmon of Kurilskoe Lake. Kronotskiy State Natural Biosphere Reserve. PetropavlovskKamchatsky. «Novaya Kniga» Publ.

Bell M.C. 1986. Fisheries handbook of engineering requirements and biological criteria, Fisheries Engineering Research Program. U.S. Army Corps of Engineers, North Pacific Division. Portland. Oregon. 290 pp.

Bugaev, V.F. 1995. Asian sockeye salmon (freshwater life, structure of local stocks, population dynamics). Moscow. KOLOS Publ. 464 pp. (in Russian)

Bugaev, V.F. 2011. Asian sockeye salmon-2 (biological structure and dynamics of local stocks abundance in the late 20th-early 21st centuries). Petropavlovsk-Kamchatsky. Kamchatpress Publ. 380 pp.

Bugaev, V.F., A.V. Maslov, and V.A. Dubynin. 2009. Ozernovskaya sockeye salmon (biology, abundance, fishery). Petropavlovsk-Kamchatsky. Kamchatpress Publ. 156 pp. (in Russian)

Clark, T.D., N.B. Furey, E.L. Rechisky, M.K. Gale, K.M. Jeffries, A.D. Porter, M.T. Casselman, A.G. Lotto, D.A. Patterson, S.J. Cooke, A.P. Farrell, D.W. Welch, and S.G. Hinch. 2016. Tracking wild sockeye salmon smolts to the ocean reveals distinct regions of nocturnal movement and high mortality. Ecological Applications. 26(4): 959-978.

Hartman, W.L., W.R. Heard, and B. Drucker. 1967. Migratory behavior of sockeye salmon fry and smolts. J. Fish. Res. Board Can. 24(10): 2069-2099.

Karpenko, V.I. 1998. Early marine period of life of Pacific salmon: monograph. Moscow: VNIRO. 165 pp. (in Russian). 
Karpenko, V.I., L.D. Andrievskaya, and M.V. Koval. 2013. Feeding and specific growth of Pacific salmon in the sea waters. Petropavlovsk-Kamchatsky. KamchatNIRO Publ. 304 pp. (in Russian).

Kirillova, E.A., P.I. Kirillov, and D.S. Pavlov. 2015. Peculiarities of the first year dispersion of juvenile sockeye salmon Oncorhynchus nerka in the basin of Kurilskoye Lake. Modern state and methods of studying freshwater ecosystems (materials all-Russian scientific conference devoted to the centenary of birth I.I. Kurenkov (October 7-9, 2015, Petropavlovsk-Kamchatsky). KamchatNIRO Publ. pp. 59-65. (in Russian with English abstract)

Kirillova, E.A., P.I. Kirillov, D.S. Pavlov, and A.O. Zvezdin. 2017. Migration patterns and phenotypic diversity of underyearlings of sockeye salmon Oncorhynchus nerka in the Ozernaya River basin (Kamchatka). Vopr. Ichthiologii. 57(6): 870-882.

Koval, M.V., E.V. Lepskaya, V.A. Dubynin, and E.A. Shevlyakov. 2014. Biological monitoring of a key salmon population: Ozernaya River sockeye salmon of West Kamchatka. N. Pac. Anadr. Fish Comm. Newsletter 35: 15-20. (Available at http://www.npafc.org).

Koval, M.V., E.V. Lepskaya, V.A. Dubynin, S.V. Shubkin, and S.A Travin. 2013. The experience of hydroacoustics study of Pacific salmon in pelagial of some Kamchatka lakes. Bulletin №8 of study Pacific salmon at Far East. Vladivostok. TINRO-Center. pp. 207-225. (in Russian)

Koval, M.V., V.G. Erokhin, A.B. Dekshtein, S.I. Subbotin, S.B. Gorodovskaya, V.I. Shershneva, and A.V. Morozova. 2011. Basic results of juvenile Pacific salmon study in coastal waters of Kamchatka during summer, 2004-2007, and 2010. NPAFC Doc. 1332. 41 pp. (Available at http://www.npafc.org)

Koval, M.V., S.L. Gorin, K.V. Kozlov, D.A. Nikulin, and M.N. Shtremel. 2012. Ichthyologic researches in estuaries of the rivers Hairuzova, Belogolovaya and Kovran (West Kamchatka) in July-August 2012. Bull. №7 of study Pacific salmon at Far East. Vladivostok. TINRO-Center. pp. 91-106. (in Russian)

Krokhin, E.M., and F.V. Krogius. 1937. Lake Kuril and biology of the sockeye salmon (Oncorhynchus nerka Walb.) spawning in its basin. Leningrad. Academy of Science USSR Publ. 165 pp. (in Russian with English abstract)

Levings, C.D. 2016. Ecology of salmonids in estuaries around the world (adaptations, habitats, and conservation). Univ. British Columbia Press, Vancouver. 388 pp.

Pavlov, D.S., E.A. Kirillova, P.I. Kirillov, and V.K Nezdolij. 2015. Downstream migration, behavior, and distribution of fish fry in the lower reaches of the Ozernaya River (Southwestern Kamchatka). Vopr. Ichthilologii. 42(1): 43-53.

Federal Scientific Research Institute of Fisheries and Oceanography. 2011. Practical manual on hydrology, Vol. 1: Hydrology: from measurements to hydrological information. VMO N168. Moscow. 514 pp. (in Russian).

Shevlyakov, E.A., and M.V. Koval. 2012. Forecast and production dynamics of pink salmon of Kamchatka. N. Pac. Anadr. Fish Comm. Tech. Rep. 8:121-125. (Available at http://www.npafc.org) 